\title{
Dynamic Changes in Serum Inhibin B Levels in 6- to 24-Month-Old Children Receiving Cryptorchidism Surgery
}

This article was published in the following Dove Press journal: International Journal of General Medicine

\section{$\mathrm{Da} \mathrm{Ma}$ \\ Zhi-Guang Yao \\ Yan-Ping Guo \\ Rui-Fa Wu}

Department of Pediatric General Surgery, Dongguan Eighth People's Hospital (Dongguan Children's Hospital), Dongguan, 523000, People's Republic of China
Correspondence: $\mathrm{Da} \mathrm{Ma}$ Department of Pediatric General Surgery, Dongguan Eighth People's Hospital (Dongguan Children's Hospital), Dongguan, People's Republic of China $\mathrm{Tel} / \mathrm{Fax}+86$ 769-86/86253

Email mada66_doc@163.com
Objective: Cryptorchidism is the most common congenital disability and is defined as the absence of one or both testicles in the scrotum during fetal development. In patients with cryptorchidism, lowered serum inhibin B levels suggest testicular dysfunction. The practical application of serum inhibin B levels in childhood remains controversial. The purpose of this study was to observe the post-operational changes of serum inhibin B levels in patients with cryptorchidism and provide evidence that serum inhibin $\mathrm{B}$ is a potential marker for the efficacy of testicular surgery.

Methods: A total of 83 male children with cryptorchidism were enrolled in this study. All the children had blood samples taken by venipuncture on the day of surgery. The serum inhibin B levels in the blood samples were measured using an ELISA kit. Paired $t$-tests were used to assess differences between the groups.

Results: The results show that, compared with the preoperative values, there was a statistically significant increase in serum inhibin B values one month after the operation in each group $(P<0.05)$. Compared with the one-month post-operation results, there were no significant changes six months after operation in each group $(P>0.05)$. However, serum inhibin B values decreased significantly in all groups at 12 months post-operation $(P<0.05)$, suggesting that serum inhibin $\mathrm{B}$ values are significantly correlated with age. Correlation analysis showed that serum inhibin B was negatively correlated with age from 6 to 36 months, and the correlation coefficient was -0.488 .

Conclusion: Serum inhibin B can be used as a short-term evaluation index of cryptorchidism surgery rather than as a long-term indicator.

Keywords: serum inhibin B, children, cryptorchidism surgery

\section{Introduction}

Cryptorchidism is the most common congenital disability in males, occurring in $1.8-4.1 \%$ of full-term newborns. ${ }^{1}$ The condition mainly affects mesenchymal cells, Sertoli cells, and spermatogenic cells in various stages of differentiation. It can cause testicular atrophy, malignant transformation, infertility, and sexual dysfunction in adulthood, thereby seriously affecting male reproductive health. ${ }^{2}$

Inhibins are heterodimeric protein hormones secreted by the Sertoli cells in the testis. ${ }^{3}$ They consist of dimers of two homologous subunits: inhibin A and inhibin B. In the testis before puberty, inhibin B is reported to be a circulating biomarker for monitoring the state of seminiferous epithelium because it is synthesized by Sertoli cells and/or germ cells. ${ }^{4}$ High inhibin B levels persist for longer periods than elevated 
follicle-stimulating hormones, luteinizing hormones, and testosterone levels. ${ }^{5}$ Many studies have emphasized that inhibin B may be a marker of testicular function. In patients with cryptorchidism, serum inhibin B levels are positively correlated with testicular function. ${ }^{6-8}$ Unfortunately, the practical application of inhibin B in childhood remains controversial. ${ }^{9}$ The purpose of this study was to observe the changes in serum inhibin B levels in patients with cryptorchidism before and after surgery and to provide an experimental basis for the effect of testicular surgery.

\section{Patients and Methods}

\section{Patients}

From October 2015 to February 2019, 83 children with cryptorchidism who were treated at the Dongguan Children's Hospital were enrolled in this study. All cases of pediatric cryptorchidism were diagnosed by physical examination and ultrasound examination in accordance with the diagnostic criteria. The children were aged between 6 and 24 months, with 32 aged 6-12 months, 27 aged 13-18 months, and 24 aged 19-24 months. There were 60 cases of unilateral cryptorchidism and 23 cases of bilateral cryptorchidism. A total of 49 of the children received traditional surgery, while 34 received laparoscopic surgery. The results are shown in Table 1.

The study was conducted in accordance with the Declaration of Helsinki and was approved by the ethics committee of the Dongguan Children's Hospital. All examinations and procedures were performed with the informed consent of the child's relatives.

\section{Methods}

One day before the samples were taken, vigorous activity and medications that could affect hormone levels were forbidden. The blood sample was quickly collected on an empty stomach between 7:00am and 9:00am from the cubital vein $(10.0 \mathrm{~mL})$. Before usage, the serum was stored

Table I General Patient Information

\begin{tabular}{|l|l|l|l|}
\hline Patient Age (Months) & $\mathbf{6 - 1 2}$ & $\mathbf{1 3 - 1 8}$ & $\mathbf{1 9 - 2 4}$ \\
\hline $\begin{array}{l}\text { Cryptorchidism type } \\
\text { Unilateral cryptorchidism }\end{array}$ & 22 & 20 & 18 \\
Bilateral cryptorchidism & 10 & 7 & 6 \\
\hline Surgical methods & & & \\
Laparoscopic surgery & 15 & 16 & 18 \\
Traditional surgery & 17 & 11 & 6 \\
\hline
\end{tabular}

at $-20^{\circ} \mathrm{C}$ until use. The concentrations of inhibin $\mathrm{B}$ were measured using the enzyme-linked immunosorbent assay (ELISA kit, Immunotech, Beckman Coulter Ltd, Webster, USA) with an assay sensitivity of $3.0 \mathrm{pg} / \mathrm{mL}$. Intra- and inter-assay coefficients of variation were $5.1 \%$ and $7.3 \%$, respectively.

\section{Statistical Analysis}

For statistical analysis, two-tailed paired $t$-tests were used to assess differences between the groups, and correlation analysis was performed between age and serum inhibin B levels. $P<0.05$ was considered statistically significant. Statistical analyses were performed using the Student's $t$-test function in bioconductor $\mathrm{R}$ package (version 3.5.1, http://www.r-pro ject.org) as 2-tailed $t$-tests assuming unequal variances.

\section{Results}

\section{Comparison of Preoperative and Postoperative Serum Inhibin B Levels in Different Age Groups}

The results showed that each group's serum inhibin B values fluctuated greatly prior to surgery, with the highest value $(258 \mathrm{pg} / \mathrm{mL})$ in the $6-12$-month group and the lowest value $(167 \mathrm{pg} / \mathrm{mL})$ in the 19-24-month group. Compared with the preoperative values, the serum inhibin B values of each group increased significantly one month after operation $(P<0.01$ or $P<0.05)$. However, there was no statistically significant difference in the serum inhibin B values measured after 6 months in each group compared with the preoperative values. Although there was an increase in the serum inhibin B levels in the 6-12-month group, there was no statistically significant difference $(P=$ 0.065) (Table 2).

\section{Correlation Analysis Between Age and Serum Inhibin B Levels}

Preliminary analysis of the results showed that serum inhibin B values were significantly correlated with age. According to the age of the children at the time of detection, serum inhibin B values were taken as abscissa and numerical values as longitudinal coordinates. Each child had four values measured for statistical analysis (preoperative, 1 month, 6 months, and 12 months after operation). The results showed that serum inhibin $B$ levels were negatively correlated with age from 6 to 36 months; the correlation coefficient was -0.488 , with $P=2.504 \mathrm{e}-11$ (Figure 1). 
Table 2 Comparison of Preoperative and Postoperative Inhibin B Levels in Different Age Groups

\begin{tabular}{|l|c|c|c|c|c|}
\hline $\begin{array}{l}\text { Age Group } \\
\text { (Months) }\end{array}$ & $\begin{array}{c}\text { Number of } \\
\text { Patients }\end{array}$ & $\begin{array}{c}\text { Preoperative } \\
\text { Value }(\mathbf{p g} / \mathbf{m L})\end{array}$ & $\begin{array}{c}\text { I-Month Postoperative } \\
\text { Value }(\mathbf{p g} / \mathbf{m L})\end{array}$ & $\begin{array}{c}\text { 6-Month Postoperative } \\
\text { Value (pg/mL) }\end{array}$ & $\begin{array}{c}\text { I2-Month Postoperative } \\
\text { Value }(\mathbf{p g} / \mathbf{m L})\end{array}$ \\
\hline $6-12$ & 32 & $258 \pm 107$ & $276 \pm 111^{* *}$ & $269 \pm 85$ & $169 \pm 75$ \\
\hline $13-18$ & 27 & $203 \pm 109$ & $209 \pm 106^{* *}$ & $209 \pm 85$ & $140 \pm 79$ \\
\hline $29-24$ & 24 & $167 \pm 74$ & $181 \pm 76^{*}$ & $168 \pm 56$ & $147 \pm 71$ \\
\hline $6-24$ & 83 & $215 \pm 105$ & $226 \pm 107^{* *}$ & $220 \pm 87$ & $153 \pm 75$ \\
\hline
\end{tabular}

Notes: Compared with preoperative value, $*^{*} p<0.01, *_{p}<0.05$.

\section{Discussion}

Cryptorchidism is the most common sexual development abnormality in boys during childhood and puberty, and its incidence can increase in premature infants, especially if they also have a low birth weight. ${ }^{10}$ Cryptorchidism can be an isolated abnormality or associated with other anatomical changes of the male genitalia. ${ }^{11}$ The exact pathogenesis of cryptorchidism is still not completely clear, and different causes lead to different degrees of testicular function and fertility damage. The descent of the testis to the scrotum is the result of a multifactorial process involving anatomical structure and hormonal function. ${ }^{11}$ It is generally considered that the testicles initially form in the abdominal cavity and then descend through a two-stage process. In the first stage, from the 8th week to the 15th week of the fetus, the testis is fixed on the internal inguinal ring by the gubernaculum. ${ }^{12}$ The Leydig cytokine named insulin-like 3 (INSL3) and its receptor relaxin family peptide receptor 2 (RXFP2) are the main regulators. In addition, androgen regulated regression of the testis cranial suspensory ligament also plays a driving role. ${ }^{13}$ In the second stage, the testicles migrate from the internal inguinal ring to the scrotum, mainly due to androgens and intra-abdominal pressure. Therefore, prematurity is associated with a higher incidence of cryptorchidism, and spontaneous decline may still occur in the first few months after birth. Anti-Müllerian hormone (AMH) is also used to evaluate the condition of cryptorchidism patients. In boys with bilateral unpalpable testes, for example, AMH, can be detected in serum indicating the presence of testicular

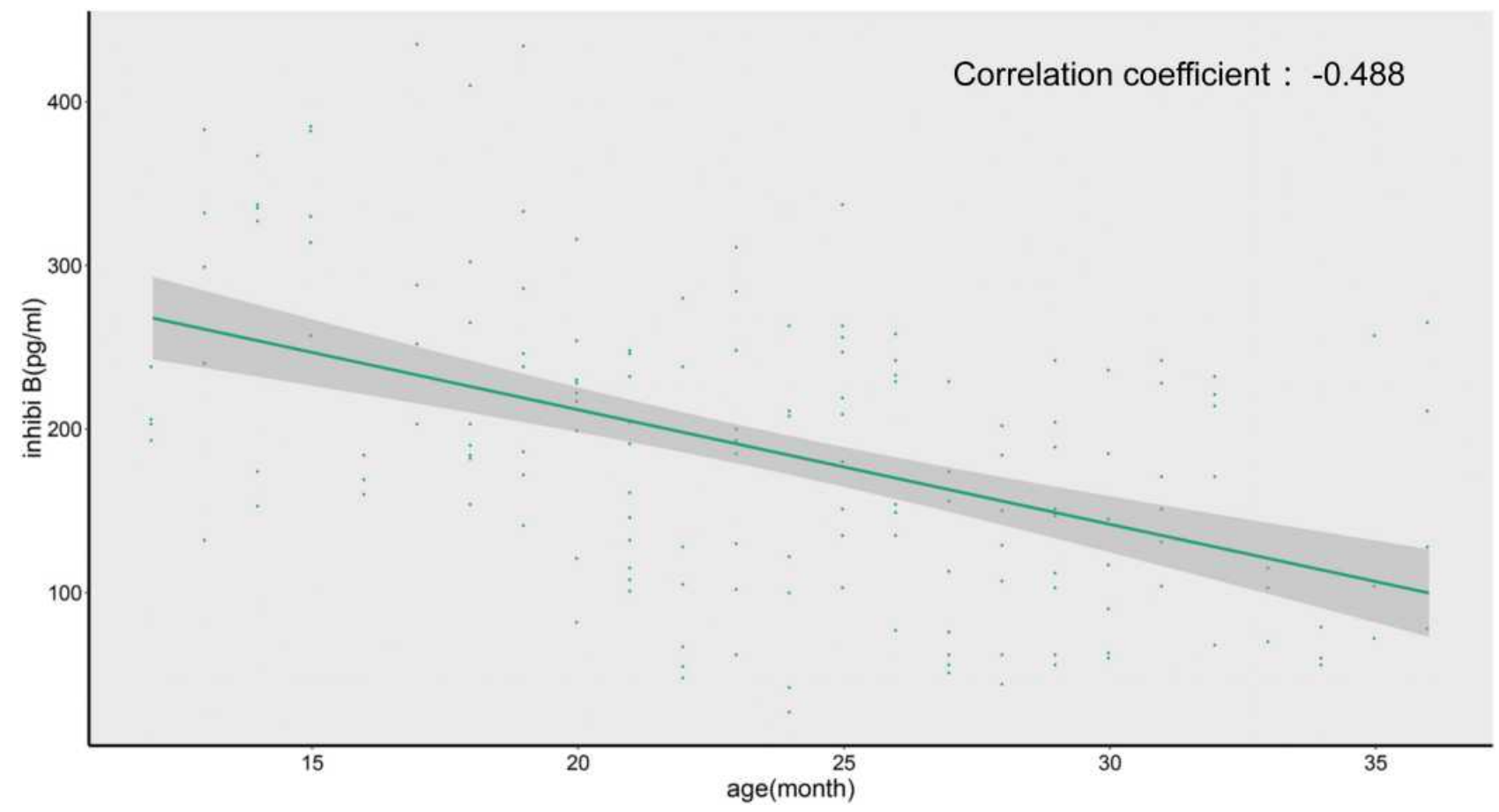

Figure I Correlation analysis between age and serum inhibin B levels. 
tissue. Some treatment guidelines and clinical studies also recommend serum AMH detection for the differential diagnosis of cryptorchidism and inguinal hernia. ${ }^{14}$

Serum inhibin B is a heterodimer glycoprotein hormone that belongs to the growth factor superfamily and consists of an $\alpha$ subunit and a $\beta$ subunit. ${ }^{4}$ It is mainly secreted by immature support cells in early childhood and is synthesized and secreted by supporting cells, spermatogenic cells, and mesenchymal cells in adulthood. ${ }^{15}$ Serum inhibin B in adolescent boys increases immediately after the increase of serum FSH, indicating that FSH can stimulate Sertoli cells. ${ }^{16}$ Prepubertal Sertoli cells can also produce serum inhibin B under the stimulation of human chorionic gonadotropin (HCG), but it cannot be produced in more mature Sertoli cells. ${ }^{17}$ A previous study found no significant difference in serum inhibin B levels between a cryptorchidism group and a control group at 6 months of age, indicating that the testicular support cell function of 6-month-old children with cryptorchidism had not been affected. ${ }^{18}$ However, serum inhibin B levels in children with cryptorchidism were significantly lower than those in the control group at 12 months of age, indicating that cryptorchidism had significantly damaged testicular support cells at 12 months of age. This supports the idea that early surgery is beneficial for the testicular development of these patients. ${ }^{19-21}$

The present study investigated the serum inhibin B levels in children with cryptorchidism before corrective surgery and at 1 month, 6 months, and 12 months after the surgery. There was a statistically significant increase in serum inhibin B levels 1 month after cryptorchidism surgery, and the follow-up results at 6 months and 12 months showed decreases in serum inhibin B levels compared to the values 1 month after surgery. This suggests that serum inhibin B levels can be used to evaluate surgical outcomes 1 month after corrective surgery but that it is unsuitable as an evaluation index 6 months or 12 months after surgery. However, a study by Irkilata showed that the level of serum inhibin B increased significantly 6 months after surgery and that it can therefore be used as a follow-up parameter after orchiopexy as a marker, which differs from the conclusion of the present study: whereas Irkilata concluded that serum inhibin B can be used as a marker after 6 months, the present study concludes that it can only be used as a marker for 1 month (the data do not support that it can be used as a marker for 6 months or longer). This difference in conclusions could be due to the age and condition of the selected patients.

Sex hormones vary greatly between prepubertal boys and between individuals. Similarly, in children with cryptorchidism, previous studies have reported that the serum inhibin B response after short-term HCG treatment varies at different ages, with the results showing that only prepubertal boys have an increased serum inhibin $\mathrm{B}$ response (older boys have no response or even a downward trend). ${ }^{17}$ In the present study, the correlation between the age of the patient and serum inhibin $B$ values was analyzed in 83 children. The results showed that in children aged between 6 and 36 months, serum inhibin $\mathrm{B}$ levels were negatively correlated with age; the correlation coefficient was -0.488 . This suggests that there is a negative correlation between serum inhibin $\mathrm{B}$ and age and that even the correlation intensity may be weak. Serum inhibin B levels dynamically fluctuate from infancy to adolescence, which is enough to cover up the effect of surgery on serum inhibin B levels. Based on the results of the present study, it can be suggested that the impact of surgery on serum inhibin $B$ levels can be masked by age-related changes in the levels. In this study, 60 cases of unilateral cryptorchidism and 23 cases of bilateral cryptorchidism were enrolled, of which 49 underwent traditional surgery and 34 underwent laparoscopic surgery. Stratified statistical analysis found no difference in clinical serum inhibin B values due to differences in surgical methods, nor were any differences identified in serum inhibin $\mathrm{B}$ values between unilateral and bilateral cryptorchidism, which may be due to the small sample size.

There are also limitations in this study, other hormone levels are not included in the statistics and analysis, such as $\mathrm{AMH}$ and testosterone, and the data of ultrasonic evaluation of patients' condition are not included. It is necessary for more detailed, systematic and comprehensive research work in the future.

\section{Conclusion}

In conclusion, there is a strong correlation between inhibin $B$ and age in patients with cryptorchidism. Serum inhibin $B$ can be used as a short-term evaluation index of the efficacy of cryptorchidism surgery, and the data of this study does not support that inhibin B can be used as a marker for long-term evaluation.

\section{Acknowledgments}

We are particularly grateful to all the people who have given us help on our article.

\section{Funding}

This study was funded by the social science and technology development project of Dongguan, Guangdong 
(No.201750715028453). The funding body had no role in the design of the study and collection, analysis, and interpretation of data and in writing the manuscript.

\section{Disclosure}

The authors declare that they have no competing interests.

\section{References}

1. Thorup J, McLachlan R, Cortes D, et al. What is new in cryptorchidism and hypospadias-a critical review on the testicular dysgenesis hypothesis. J Pediatr Surg. 2010;45(10):2074-2086. doi:10.1016/j. jpedsurg.2010.07.030

2. Ong C, Hasthorpe S, Hutson JM. Germ cell development in the descended and cryptorchid testis and the effects of hormonal manipulation. Pediatr Surg Int. 2005;21(4):240-254. doi:10.1007/ s00383-005-1382-0

3. Barakat B, Itman C, Mendis SH, Loveland KL. Activins and inhibins in mammalian testis development: new models, new insights. Mol Cell Endocrinol. 2012;359(1-2):66-77. doi:10.1016/j.mce.2012.02.018

4. Makanji Y, Harrison CA, Robertson DM. Feedback regulation by inhibins $\mathrm{A}$ and $\mathrm{B}$ of the pituitary secretion of follicle-stimulating hormone. Vitam Horm. 2011;85:299-321. doi:10.1016/B978-0-12385961-7.00014-7

5. Chada M, Průsa R, Bronský J, et al. Inhibin B, follicle stimulating hormone, luteinizing hormone and testosterone during childhood and puberty in males: changes in serum concentrations in relation to age and stage of puberty. Physiol Res. 2003;52(1):45-51.

6. Braga LH, Lorenzo AJ. The changing elaboration of inhibin $b$ in patients with unilateral testicular maldescent vs vanished testis. J Urol. 2015;193(5):1465-1466. doi:10.1016/j.juro.2015.02.076

7. Lee PA, Coughlin MT. Fertility after bilateral cryptorchidism. Evaluation by paternity, hormone, and semen data. Horm Res. 2001;55(1):28-32. doi:10.1159/000049960

8. Huang X, Bai Q, Yan LY, Zhang QF, Geng L, Qiao J. Combination of serum inhibin B and follicle-stimulating hormone levels can not improve the diagnostic accuracy on testicular sperm extraction outcomes in Chinese non-obstructive azoospermic men. Chin Med $J$ (Engl). 2012;125(16):2885-2889.

9. Radicioni AF, Anzuini A, De Marco E, Nofroni I, Castracane VD, Lenzi A. Changes in serum inhibin B during normal male puberty. Eur $J$ Endocrinol. 2005;152(3):403-409. doi:10.1530/eje.1.01855
10. Mathers MJ, Sperling H, Rübben H, Roth S. The undescended testis: diagnosis, treatment and long-term consequences. Dtsch Arztebl Int. 2009;106(33):527-532. doi:10.3238/arztebl.2009.0527

11. Klonisch T, Fowler PA, Hombach-Klonisch S. Molecular and genetic regulation of testis descent and external genitalia development. Dev Biol. 2004;270(1):1-18. doi:10.1016/j.ydbio.2004.02.018

12. Braga LH, Lorenzo AJ. Cryptorchidism: a practical review for all community healthcare providers. Can Urol Assoc J. 2017;11(Suppl 1-2S):S26. doi:10.5489/cuaj.4343

13. Satchell L, Glister C, Bleach EC, et al. Ovarian expression of insulin-like peptide 3 (INSL3) and its receptor (RXFP2) during development of bovine antral follicles and corpora lutea and measurement of circulating INSL3 levels during synchronized estrous cycles. Endocrinology. 2013;154(5):1897-1906. doi:10.1210/ en.2012-2232

14. Matuszczak E, Hermanowicz A, Debek W, et al. Serum AMH concentration as a marker evaluating gonadal function in boys operated on for unilateral cryptorchidism between 1st and 4th year of life. Endocrine. 2012;41(2):334-337. doi:10.1007/s12020-011-9551-5

15. Bertola DR, Yamamoto GL, Almeida TF, et al. Further evidence of the importance of RIT1 in Noonan syndrome. Am J Med Genet Part A. 2014;164(11):2952-2957. doi:10.1002/ajmg.a.36722

16. Young J, Couzinet B, Chanson P, Brailly S, Loumaye E, Schaison G. Effects of human recombinant luteinizing hormone and follicle-stimulating hormone in patients with acquired hypogonadotropic hypogonadism: study of Sertoli and Leydig cell secretions and interactions. J Clin Endocrinol Metab. 2000;85(9):3239-3244. doi:10.1210/jcem.85.9.6811

17. Christiansen P, Anderson AM, Skakkebæk NE, Juul A. Serum inhibin $\mathrm{B}, \mathrm{FSH}, \mathrm{LH}$ and testosterone levels before and after human chorionic gonadotropin stimulation in prepubertal boys with cryptorchidism. Eur J Endocrinol. 2002;147(1):95-101. doi:10.1530/eje.0.1470095

18. Monsees TK, Franz M, Gebhardt S, Winterstein U, Schill WB, Hayatpour J. Sertoli cells as a target for reproductive hazards. Andrologia. 2000;32(4-5):239-246. doi:10.1046/j.14390272.2000.00391.x

19. Esposito S, Cofini M, Rigante D, et al. Inhibin B in healthy and cryptorchid boys. Ital J Pediatr. 2018;44(1):81. doi:10.1186/s13052018-0523-8

20. Kolon TF, Herndon CD, Baker LA, et al. Evaluation and treatment of cryptorchidism: AUA guideline. J Urol. 2014;192(2):337-345. doi:10.1016/j.juro.2014.05.005

21. Bertelloni S, Wünsch L. Management of undescended testis: a debate. Sex Dev. 2019;13(1):1-2. doi:10.1159/000496464
International Journal of General Medicine

\section{Publish your work in this journal}

The International Journal of General Medicine is an international, peer-reviewed open-access journal that focuses on general and internal medicine, pathogenesis, epidemiology, diagnosis, monitoring and treatment protocols. The journal is characterized by the rapid reporting of reviews, original research and clinical studies across all disease areas. The manuscript management system is completely online and includes a very quick and fair peer-review system, which is all easy to use. Visit http://www.dovepress.com/ testimonials.php to read real quotes from published authors. 